Annales Missiologici Posnanienses t. 25 (2020), s. 103-115

doi: $10.14746 / \mathrm{amp} .2020 .25 .7$

ORCID: 0000-0001-6947-9652

FREEBORN KIBOMBWE

St. Joseph's Theological Institute - SJTI (South Africa)

\title{
Miranda Prorsus: \\ An Encyclical Letter of Pope Pius XII on Motion Pictures, TV and Radio - its Impact on the Catholic Church Media in Zambia Today
}

\section{Introduction}

It has been over sixty years since the encyclical Miranda Prorsus by Pope Pius XII was written in 1957. The encyclical's focus was on the three key media for communication, that is, The Motion Picture (film), Television and Radio. This was the only second encyclical to be written in the twentieth century ${ }^{1}$ by a Pope. This article will reflect on the nature and importance of Miranda Prorsus and how the Zambian Catholic Church has responded to this call of using the media for evangelization. Two forms of media have been prominent by the Zambian Catholic Church, that is two television stations and nine radio stations. One of the Television Station Lumen TV is run by the Zambia Conference of Catholic Bishops (ZCCB) and the other Loyola TV is being run by the Jesuits. And the radio stations are located in the nine dioceses out of the eleven dioceses of Zambia. Therefore, the article will give a short introduction to the document Miranda Prorsus and its context; the Catholic teaching on social communication; understanding the perspective on the means of social communication on cinema, radio and television according to the document; a general overview of the media landscape in Zambia; the Catholic media landscape in Zambia and finally, I will look at the implication of Miranda prorsus for evangelization in Zambia.

\footnotetext{
${ }^{1}$ The first encyclical to be written was Vigilanti Cura (Be Vigilant) by Pope Pius XI; the document focused on the aspect of cinema and the moral obligations that the film industry was cale industry.
} 


\section{Miranda Prorsus}

The $8^{\text {th }}$ of September, 1957 the Feast of the Nativity of Our Mother Mary will remain a great year for the Catholic Church in as far as the Church's involvement in media is concerned. In this year a landmark encyclical of the $20^{\text {th }}$ Century entitled Miranda Prorsus was written by Pope Pius XII. The encyclical that in 2017 saw the Church commemorate 60 years since its publication. The encyclicals three main areas of focus were on: Motion Pictures (Film), Television (TV) and Radio. The church also recognized the fact that these inventions brought about great joy and are welcome in the world. However, the Church must watch with a "mother's watchful concern care and anxiety." (MP 3), that these inventions bring with them. The document further underlines the fact that even if these media bring about that enjoyment there should also be an alertness especially as regards the Children who are exposed to uncensored programs as stated in the document; "this vigilance of hers springs from the very commission she has received from the divine Redeemer, for, as must be obvious to all, these new facilities have a very great contribution to make to the way in which individuals, and indeed the whole of human society, shall think and act" (MP 3). Despite all the challenges that these three forms of media seem to have brought especially in light of the 1950s context, the Pope reminds us even today that these inventions are also meant to unify the world. Especially, in these modern times that such traditional media as well as modern means like social media have been noted as facilitators of peace and unity in light of evangelization.

\section{The Catholic Church's Teachings on Social Communications}

About Christian teachings and communication, the Pope in this encyclical asks three pertinent questions to those involved in the media and especially the Christians responsibility at large. He asks as follows: What is the object of communication for Christian communication? What does true freedom mean in light of principles and errors of communication? And finally, what is the role of public authorities and professionals? Therefore, it is in this light that the Pope reiterates the key objective of Christian communication that, "all these means which men use to communicate with one another should be directed towards the realization of man's high vocation, to be, as it were, the minister of the gifts of God" (MP 19). It is out of this objective that we are reminded about the importance of watching out for key principles and errors of communication something that is invented wonderfully but also has its own follies. The Church has a moral duty as teacher of doctrine in as far as principles 
are concerned. While the document affirms its importance for participating in these means of communication for evangelization, one can easily detect that the concern at that time even today is about the challenges that communication instruments bring to the fore.

On the errors we are reminded of the fact that they do happen or had been happening with these technological inventions without impunity. These principles were seen as counter-productive against principles of the Church teaching on morals and objective truth. These means of communication were not to be used to propagate anything just for the sake of entertainment; these three inventions and "their particular value is that they can serve to educate the mind and foster virtue, and by so doing make no small contribution to the task of organizing and molding aright the civil society of our times" (MP 33). With this suggested approach indeed, evangelization can truly take place world over without neglecting the challenges as highlighted in Miranda Prorsus.

\section{Means of Audio-Visual Communication}

In this part of the document Pope Pius XII was trying to emphasize a fourfold aspect if you will on the means of how truth is communicated through the audio visual expression. The first aim therefore of these instruments (motion picture, Radio and Television) were to make sure that they serve both truth and virtue. For it is in truth and virtue the Church as well as the secular state holds its members as Christians and Citizens respectively to accountability and responsibility. Besides truth, three other important aspects must be observed in as far as the means of audio-visual communication are concerned, and these are: Information, Teaching and Entertainment. It is therefore imperative that media education was to be prioritized as important to check on what entertainment was being presented. In order for all these to be achieved the Pope urges the Church in various continents to have national offices that would implement some of the suggestions made on how the media could be used mainly for truth telling and evangelization. The encyclical emphasized the fact that using the media is not only the preserve of the clergy in this instance but also a duty for all lay Catholics to also be involved in using the media for the purposes of evangelization and not just entertainment.

It is from this background and case in point that I will now present what the encyclical states concerning each of the three media that this document addresses, that is, on Motion Pictures, Radio and Television. How does each of these media help in the whole aspect of evangelization in their uniqueness? 


\section{Miranda Prorsus and Motion Pictures (Film)}

Pope Pius XII's opening statement goes to the heart and purpose of his views on motion picture (film) by stating that, "it is all together vital that all those engaged in the industry shall be animated individually and jointly with a right conscience and the will to cooperate in the production and distribution of credible films" (MP 55). From the onset one can detect the fact that in the Pope's view, we ought to embrace the film industry but at the same time be able to be aware and critical of what films can do to the conscience and moral obligation to its members. The emphasis was to remind all of us that one cannot take for granted what the media promotes, especially if values of the Church are compromised. Therefore, it is clear in this document that the role of "gatekeepers" if you will could never have been underestimated as emphasized. Today, film critics like Fr. Peter Maloney ${ }^{2}$ have continued to carry out this task with energy and is respected world over for his ability to review and rate films. Films that cannot only cater for the Theology of evangelization but also for the moral and obligation of every Christian's conscience. The Pope's concern under the film presentation is that professionals such as Critics, Theater Managers, Distributors, Actors and Producers and Directors are key in making sure that films produced represent some Gospel values and truth. In other words, they should assist in producing films that are worthy of the Gospel calling; films that were capable of enhancing the importance of evangelization through this form of media.

\section{Miranda Prorsus and Radio}

The other specific media of mass communication to be addressed by Pope Pius XII was the radio which was one of the earliest medium in the development of the instruments of communication. As a means for evangelization, the Pope described this communication medium as of extreme importance and that "the most outstanding service that radio can render is to illumine and instruct men's minds, and progressively to raise their intellects to the contemplation of divine and enduring truth" (MP 83). The document highlights five key areas to be focused on in as far as radio is concerned: Development and possibilities; duty of receivers; Religious programs; Catholic radio stations and finally

${ }^{2}$ Fr. Peter Maloney MSC is an Australian Priest and film critic. He served as President of the Catholic Film Offices of the Pacific (1989-1998). He was elected as President of OCIC (The International Catholic Organization for Cinema). When OCIC merged with UNDA (the International Catholic Organization for Radio and Television) to form SIGNIS (The World Catholic Association for Communication) he was elected the first President (2001-2005). Peter Maloney MSC. Ytu.edu. au (Accessed September 5, 2017). 
program responsibilities. This is the context in which evangelization through radio must be observed and adhered to considering the fact that the process of evangelization cannot just happen in a vacuum but in a context that enhances it. It is also important to highlight the aspect of Religious programming; which is presented in the encyclical as an important and supposedly fundamental aspect of radio programming. The Pope indicates that, "we are constrained, venerable brethren, to exhort you paternally to make every effort proportionate to the needs and resources of your respective dioceses to increase and render more effective the number of programs which deal with Catholic interest" (MP 96). The Pope was clear that all Catholic Radio stations must put in the forefront the formation of Catholics involved in radio production to be formed accordingly in Church teaching and promotion of sound moral focus that enhances the process of evangelization.

\section{Miranda Prorsus and Television}

Finally, the encyclical addresses the third aspect of these means of communication that is Television as one of the particular focus besides the other two that is Film and Radio. Under this aspect the encyclical looks at Criteria and Possibilities; Religious programs; influence on family and youth (in as far as Responsibilities, Difficulties and solutions as well as the Role of Educators are concerned). All these aspects mentioned above are of vital importance in as far as Catholic media evangelization is concerned. According to the Pope; the importance of television for evangelization through its religious programming can prepare one for a good reception to receive the word of God or any spiritual nourishment, "it is essential that those who direct the production of televised films make sure that there is no neglecting of the principles of religions and morality" (MP 114). And through such presentation evangelization can take place in respect of Churches and communities around the world. The television as a popular medium was seen as a medium of great interest with so much potential for real evangelization that is visible as compared to radio. Most of the movies about the Life of Jesus have been filmed to bring the Gospel text to a live reality and taking us into the early centuries of Jesus' life with his disciples. The use of television, is bringing evangelization right to the door steps of Catholics especially those that are unable to be mobile for health reasons. In these times of Covid-19, television has become one of the most popular medium for evangelization, especially from channels aired on EWTN Television (Eternal Word Television Network) out of Alabama (USA). Television as an influential medium was given attention as it is quite different to radio and most instances to the film shows. One of the strengths of televi- 
sion I gather in this document is the fact that, it is quite personal and intimate for family outreach, as it brings the family together in a home when shows are being televised. A plus for the programming especially in the form of evangelization. Certainly, Christmas and the Easter Season remain the most favorite, usually when liturgical services like Mass are conducted by the Pope from Rome or any particular events of Christian values are presented.

\section{Conclusion}

This section has attempted to highlight what the Pope considers important in as far as using the means of social communication in this case motion pictures, radio and television are concerned. The emphasis in all these three medium is that we ought first to appreciate these inventions in our modern world as they have become greater tools for spreading critical information and for the purposes of evangelization for that matter. It is not enough to use these instruments to watch or listen to but to be able to detect in prudence good messages from harmful ones. Messages that are in line with the principles and values of the Church and at the same time principles that promote the essence of evangelization that of making Jesus Christ known world over. And in order to foster these ideals, dioceses all over the world were reminded to make setting up of communication offices and training of both clergy and laity a certain priority. Thankfully, one can attest to the fact that in many dioceses around the world a lot has been achieved in making offices present for the media. My attestation is the fact that in my own home country Zambia, this has really taken place since the 1970s, with people appointed who have studied and are media trained.

I will now focus on the media landscape in Zambia as this is the context in which the importance of this encyclical Miranda prorsus has implications for evangelization in Zambia.

\section{The Media Landscape in Zambia}

The landscape in Zambia has dramatically changed since 1991 when Zambia as a country reverted to multi-partism. For 27 years Zambia was ruled as a one party state by the United Nation Independence Party (UNIP) under Dr. Kenneth David Kaunda, the founding Father of the Republic of Zambia. The political landscape does indeed affect to some extent how the media, education, culture, sports to mention but a few are influenced. Zambia has undergone Three Republican stages through the constitutional changes. The first Republic was from 1964-1972 (Multi Party State); the Second Republic was 
from 1972-1991(One Party State) and the current republic which is our Third Republic stage since 1991 when the Movement for Multi-Party Democracy (MMD) took over power from Dr. Kenneth Kaunda and begun liberalizing the economy from Parastatals to Private and joint partnership economy. The Manifesto states that:

The MMD government recognizes that the media is an effective too for the provision of information necessary for the public participation in democratic governance. As a democratic nation, Zambia needs to uphold freedom of expression and that of the media, to ensure free flow of ideas and provide a means of feedback from the public to government and vice-versa. (MMD Manifesto 2001) ${ }^{3}$.

It is in this context that the Catholic Media also evolved from print to the electronic form. However, suffice to say that statistically at the time of writing this article the number of various media as per Independent Broadcasting Authority (IBA) ${ }^{4}$ stood as follows: Radio Stations (110); Community Television Stations (10); Community Free to Air (27); Public Television Broadcasting (4); Satellite Subscription Broadcasting (5); Terrestrial Subscription Broadcasting (1); Cable Subscription Television (1) and Land Rights Broadcasting Services (2). The number of media operating in Zambia shows that the level of "liberalization of the airwaves" can be considered as unprecedented on the continent save for few countries if not fewer. It is in this context that the Catholic Church found itself participating in the "Media-sphere" of Zambia alongside the private, community and commercial media. Though the Catholic media is classified under community, I would say it is in its own right a religious medium as it addresses matters of faith with the primary focus being evangelization.

\section{Miranda Prorsus and the Catholic Media in Zambia}

The Catholic Church in Zambia has been proactive in as far as media establishment is concerned. Even in the time of the UNIP government the print media under National Mirror which was an ecumenical newspaper gained popularity among the people in Zambia. The National Mirror was considered

${ }^{3}$ The Mass Media, Art. 7.8. The Manifesto further highlights the MMD Government's achievements from 1991-2001 and states the vision of what was yet to be achieved projecting development from 2001 to 2011. Of course, in 2011 the MMD Government lost the election the Patriotic Front (PF) led by the late resilient Michael Chilufya Sata (who died in October, 2014).

${ }^{4}$ Cited in MISA Zambia State of the Media First Quarterly Report (January to March, 2017) from The Independent Broadcasting Authority (IBA) Report. 
a private paper and people trusted that indeed it would "mirror" real issues or issue-based journalism which many people were craving for. In defining what the term "issue" means Edem Djokotoe says that an issue "is a subject that arises for discussion; and is usually capable of invoking strong emotional and ideological reactions, essentially because people are likely to have divergent view on that particular issue." (Djokotoe 12). As others would say our use of the media is to make sure that they become means for being the "voice of the voiceless." They become the center of integral evangelization; evangelization that encompasses the Gospel but also aspects of development for the livelihood of the people we are sent to evangelize.

\section{Overview of the Catholic Media Landscape}

In the last 20 years we have seen the growth of the Catholic Media in Zambia to unprecedented levels to the delight of not only the Catholic Church leadership, lay Catholics but also non Catholics and other faith groups like Moslems. Suffice to indicate that this development, was enhanced first, by the need to use these technologies for evangelization purposes. Because in some places of Zambia it is very difficult to reach out to the people especially the poor in remote or rural areas of the country. That was the purpose of establishing our own radio station (Oblate Radio Liseli) ${ }^{5}$ in the Western part of Zambia (Mongu Diocese) due to constant annual floods in the plains that can last as long as eight (8) months every year. The Catholic radio industry is the most developed and widely spread in the country followed by a couple of magazines like Speak-Out and Icengelo. In fact, the earliest record of the Catholic Church setting up a weekly Tabloid was in 1961, known as "The Leader"; according to Kenny Makungu who wrote that the purpose of the Tabloid was:

To bridge the gap between two newspapers ("Central African Mail" and "Daily Mail") and provide balanced reading for readers. "The Leader" however, closed shop in August 1962 after publishing for slightly over a year. But seven months later, the Catholic Church started another newspaper the "Northern Star". It became the first newspaper to practice interpretive policy...it was non-partisan and without racial bias (Makungu, X).

Recently, the Zambia Conference of Catholic Bishops (ZCCB) have set up a television station known as Lumen TV, as well as, the Society of Jesus (Je-

${ }^{5}$ The Radio is solely owned by my Congregation the Missionary Oblates of Mary Immaculate - Oblate Zambia Delegation. The name Liseli means Light from the local dialect language of Silozi spoken in the Western part of Zambia (Western Province) in the Catholic Diocese of Mongu. 
suits) have set up their own television station known as Loyola TV. Both are based in the Capital City of Lusaka but are able to be accessed all over Zambia if one has the DSTV (Direct Satellite TV) run by Top Star company from China or the DSTV of South Africa.

One can also not rule out the fact that one of the earliest form of evangelization by the Catholic Church was to use production studios for making religious film that could be distributed to the national broadcaster for airing. These production studios have continued to exist side by side with the two existing television now.

\section{Catholic Church and Media in Zambia: Radio, Television and Film}

On Radio: in 1996, the late Bishop Emeritus Dennis De Jong was the first bishop to set up a radio station in Ndola Diocese on the Copperbelt among all the dioceses in Zambia. Today, these archdioceses and Dioceses: Ndola Diocese (Radio Icengelo); Lusaka Archdiocese (Radio Yatsani Maria); Chipata Diocese (Radio Maria); Mongu Diocese (Oblate Radio Liseli); Livingstone Diocese (Radio Mosi-Oa-Tunya); Mansa Diocese (Radio Yangeni); Solwezi Diocese (Radio Kangabanga); Monze Diocese (Radio Chikuni); Kasama Archdiocese (Radio Lutanda). The following two dioceses Kabwe and Mpika are yet to establish a radio station each respectively at least by the time of publishing this article. Therefore, 9 out of 11 dioceses have a radio stations, representing about $8 \%{ }^{6}$ of the radio stations operating now in Zambia are owned by the Catholic Church. The radio is still a popular medium for evangelization, news and entertainment in Zambia and many parts of the continent of Africa. Therefore, in this case most bishops in Zambia, want to use this means in particular to reach out to the Catholic population and the public in general with faith based as well as development programs. Our Catholic ethos for evangelization using the radio is that it be for integral evangelization; evangelization that touches the soul and the flesh of humanity.

On Television: the current situation prevailing in Zambia is the fact that the setting up Catholic Televisions has been will achieved. Two televisions stations are now in operation, that is, Lumen TV which is being run by the Zambia Conference of Catholic Bishops (ZCCB) and Loyola TV which is being run by the Congregation of the Society of Jesus known as Jesuits. The response has been overwhelming to both stations and people all over the coun-

${ }^{6}$ This $8 \%$ is represented from the total number of radio stations reported earlier in this paper according to the Independent Broadcasting Authority (IBA) statistics of 110 as of the first quarter of 2017. 
try are happy not only Catholics but the general populace. The two television stations are leading in producing programs in line with evangelization and the promotion of good Christian and human values. This is definitely the answer to the call of Miranda Prorsus by Pope Pius XII who insisted that the Church takes initiative to be involved in using these new means of communication for evangelization and moral formation of conscience. He would certainly be proud of what has been achieved so far not only the Zambian context but the world over.

On Film: the Catholic Church's two major production studios operating full time are "Loyola" Production and Catholic Media Services owned by the Society of Jesus (Jesuits) and the Zambia Conference of Catholic Bishops (ZCCB) respectively. The two production houses have been good at producing documentaries, and short story programs of evangelization in nature. Other religious functions of various dioceses and by the national conference itself as well as regional integration have been produced and preserved. One can only hope that in future, these two productions and hopefully more that will follow can begin to participate in the film industry to bring about films that have a religious character and promote ethical discipline to the film industry as per directives in Miranda Prorsus.

\section{Implication of Miranda Prorsus on the Catholic Church in Zambia and its evangelization}

The continent of Africa has come of age in as far as the use of media is concerned. This reality was reiterated by Pope John Paul II in the encyclical Ecclesia in Africa in which he stated that, "the Synod had much to say about social communications in the context of the evangelization of Africa, carefully taking into account present circumstances" (EA 122). The development of the media in Africa springs from the very fact that the traditional forms of communication such as songs, dance, instruments have played a major role in communicating the message. The Pope further affirmed this when he wrote that the traditional forms of communication are "vehicles of wisdom and soul of the people, they are a precious source of material and of inspiration for the modern media" (EA 123). Hence, the modern media, one can say are an extension of what we in Africa have always valued, that is, using instruments, dance, songs, folktales to explain and "broadcast" realities from one village to another. Therefore, the media and modern technologies are a blessing and in particular for the Catholic Church in Zambia for they help to amplify this reality of the African culture versus the new media. A foundation upon which the process of evangelization can take place. 
After a snap survey of the media industry in Zambia generally and particularly under the Catholic Church one can see that the level of influence in as far as the film, radio and TV industry is concerned will continue to grow. These media are clearly being used in Zambia by the Catholic Church in order to evangelize. Suffice to mention here that the essence of being involved in media and especially through the use of radio and the two television stations is to reach out to various groups of people not only Catholics with the Good News (For evangelization) but to people of other faiths and goodwill. The question is how do we as Catholic Media particularly in Zambia make relevant the document Miranda Prorsus talking about the same means of communication the film, Radio and Television. The Catholic media in Zambia in light of carrying forward the vision of Pope Pius XII about the role of the media in the world in particular the means of Film, Radio and TV ought to highlight the basic principles that we have delt with earlier as follows:

a. That the new developments in Zambia carryout the mandate by making sure that religious production is enhanced and adhered to all the time for better evangelization

b. That the purpose of production is to promote morally viable and educative movies that make people appreciate their human dignity and promotes the faith

c. That these media are to help the integration of families rather than splitting them

d. That youth are cared for and helped to be responsible in as far as media education (critical look at media) is concerned

e. That producer, directors, actors, distributors and all those involved in movie know of their responsibilities in as far as content is concerned

f. That Bishops participate in making an awareness to all those involved in production of their obligations; their office can influence a lot if they take interest is in this new evangelization tools

g. That national office be created if not yet done so that they can have directly influence from a structured and formal offices

h. That priest and religious be trained in these areas of communication so that they are able to impart and share what is morally good to watch or not

i. That the media becomes the tool of proper catechesis and formation for mission.

\section{Conclusion}

Miranda Prorsus remains as one of the most influential document to be produced in the $20^{\text {th }}$ Century by a Pope and remains valid to this day. It has 
been over 60 years since its publication (1957-2017). It is a reminder to all of us that there is still more to be done in terms of making Catholics involved in the media be it clergy, religious or laity to understand and know this reality. In particular, the Catholic Church in Zambia through the bishop's conference can be commended for their boldness to establish radio stations in various dioceses and above the establishment of the Catholic station - Lumen TV and also for the Jesuit's Loyola TV. I can only hope that the challenges raised in Miranda Prorsus will continue to be taken to heart by those involved in the media. Especially, for those involved in Catholic media in as far as moral education and formation is concerned to protect the integrity of what it means to be good journalists and media practitioners inspired by the Church's thoughts and teachings in various document the before and after "Miranda Prorsus so that the essence of evangelization may be carried out using the most common means used by the world that is, film, Radio and Television".

\author{
MIRANDA PRORSUS: AN ENCYCLICAL LETTER OF POPE PIUS XII \\ ON MOTION PICTURES, TV AND RADIO - ITS IMPACT \\ ON THE CATHOLIC CHURCH MEDIA IN ZAMBIA TODAY
}

\title{
ABS T R A C T
}

This article reflects on the sixty years marking the anniversary of the encyclical letter Miranda Prorsus by Pope Pius XII. Miranda Prorsus was the first document written in 1957 by the Church to reflect on the three important means of communication: Motion Pictures (Film), Television (TV) and Radio. It highlighted the importance of these "remarkable technical inventions" to aid humanity in as far as development and understanding the media was concerned. Each of these three instruments of communication is examined in both the strengths and weaknesses they carry, but much more, how they can play a role in advancing humanity in the area of morality and truth telling. The article tries to use some of the important highlights in the context of Zambia my country that has embraced these means of communication with radio stations set up by the respective Bishops and a Television soon to be launched by the Zambia Conference of Catholic Bishops (ZCCB). In retrospect the article tries to show how these means and technical inventions can become handy in as far as the evangelization is concerned.

Keywords: Miranda Prorsus; Zambia; Catholic media; evangelization

Słowa kluczowe: Miranda Prorsus; Zambia; media katolickie; ewangelizacja 


\section{List of Shortcuts}

MP - Pius XII, Miranda Prorsus: The Cinema, Sound Broadcasting and Television. London: Catholic Truth Society

EA - Ecclesia in Africa (The Church in Africa)

ZCCB - Zambia Conference of Catholic Bishops.

\section{BIBLIOGRAPHY}

Djokotoe, Edem. An Issue-based Journalism Handbook. Lusaka: MISA Zambia Publications, 2004. Makungu, M. Kenny. The State of the Media in Zambia - From the Colonial Era to 2003. Lusaka: MISA Zambia Publication, 2004.

MISA Zambia (2017). State of the Media in Zambia for the First Quarter (January - March). Lusaka: MISA Publication, 2017. Lusaka.

Movement for Multi-Party Democracy - MMD (2001). MMD Manifesto. Lusaka: Self-Published, 2001.

Pius XII. Encyclical Letter - Miranda Prorsus: The Cinema, Sound Broadcasting and Television. London: Catholic Truth Society, 1957.

Freeborn IsaAC Kibombwe OMI, a member of the Oblate Zambia Delegation in Southern Africa. He is the past Delegation Superior of Zambia from 2011-2017. Besides pastoral ministry in parishes, he has been working mainly in media especially being the founder and establishing the Oblate Radio Liseli (Light), a radio wholly owned by the Oblates in Zambia located in the Diocese of Mongu (Western Zambia). He has taught in the Department of Social Sciences - Mass Communication and Public Relations at Cavendish University of Zambia a private University. Was instrumental in setting up the Department of Journalism and Media studies at the Zambia Catholic University branch in Lusaka (Capital City) and lectured there too. He has been the Episcopal Conference of Zambia member of consultors in setting the Lumen TV Zambia (A television station for the Bishops of Zambia to be launched soon). He holds a B.Phil., (Urbaniana); M.Div., (Oblate School of Theology, Texas); MA Communication Arts (University of the Incarnate Word - Texas) and a Doctor of Ministry (D. Min) in Pastoral Theology and Media from Oblate School of Theology - Texas). He is currently assigned to the Oblate Scholasticate as formator and Theological Institute in South Africa. 
